\title{
Herpes Simplex Vaccines: Prospects of Live-Attenuated HSV Vaccines to Combat Genital and Ocular Infections
}

\author{
Brent Stanfield $^{1} \cdot$ Konstantin Gus Kousoulas $^{1}$
}

Published online: 1 July 2015

(C) Springer International Publishing AG 2015

\begin{abstract}
Herpes simplex virus type 1 (HSV-1) and its closely related herpes simplex virus type 2 (HSV-2) cause important clinical manifestations in humans including acute ocular disease and genital infections. These viruses establish latency in the trigeminal ganglionic and dorsal root neurons, respectively. Both viruses are widespread among humans and can frequently reactivate from latency causing disease. Currently, there are no vaccines available against herpes simplex viral infections. However, a number of promising vaccine approaches are being explored in preclinical investigations with few progressing to early-phase clinical trials. Consensus research findings suggest that robust humoral and cellular immune responses may partially control the frequency of reactivation episodes and reduce clinical symptoms. Liveattenuated viral vaccines have long been considered as a viable option for generating robust and protective immune responses against viral pathogens. Varicella zoster virus (VZV) belongs to the same alphaherpesvirus subfamily with herpes simplex viruses. A live-attenuated VZV vaccine has been extensively used in a prophylactic and therapeutic approach to combat primary and recurrent VZV infection, indicating that a similar vaccine approach may be feasible for HSVs. In this review, we summarize preclinical approaches to HSV vaccine development and current efforts to test certain vaccine approaches in human clinical trials. Also, we discuss the potential advantages of using a safe, live-attenuated HSV-1
\end{abstract}

This article is part of the Topical Collection on Virology

Konstantin Gus Kousoulas

vtgusk@1su.edu

1 Division of Biotechnology and Molecular Medicine and Department of Pathobiological Sciences, School of Veterinary Medicine, Louisiana State University, Baton Rouge, LA 70803, USA vaccine strain to protect against both HSV-1 and HSV-2 infections.

Keywords Herpes simplex · Vaccine · Ocular · Genital · Keratitis $\cdot$ Live-attenuated $\cdot$ Immune evasion

\section{Introduction}

The Alphaherpesviruses The Alphaherpesvirinae subfamily of Herpesviridae family contains the genera Simplexvirus (HSV) and Varicellovirus (varicella zoster virus (VZV)). Generally, alphaherpesviruses replicate rapidly in infected cells causing extensive cytolysis within $24 \mathrm{~h}$ post infection. An important property shared by all alphaherpesviruses is their ability to infect neurons establishing latency primarily, but not exclusively, in sensory ganglionic neurons. Herpes simplex virus type 1 (HSV-1) and herpes simplex virus type 2 (HSV-2) cause orofacial cold sores and severe ocular disease and blindness as well as genital ulcers, while VZV causes chickenpox/shingles in naïve younger individuals and in adult patients with weakened immune systems. HSVs are the prototypic viruses of the alphaherpesvirus subfamily, which also contains economically important animal viruses including Marek's disease-like virus (MDV), bovine herpesvirus type 1 (BHV-1), pseudorabies virus (PRV), and others. Alphaherpesviruses, as it is the case with many other viruses, have evolved specialized functions to subvert the host immune responses facilitating the establishment of latency in sensory neurons. Perturbations of the host immune system can often lead to viral reactivation from latency, suggesting the presence of an elaborate virally specified system for sensing host immune status particularly in the context of immune system interaction with neuronal cells. 
HSV Infectivity HSV-1 enters neuronal cells via a $\mathrm{pH}-$ independent fusion of the viral envelope with neuronal plasma membranes, but it can enter a wide range of non-neuronal cells via either $\mathrm{pH}$-independent or $\mathrm{pH}$-dependent endocytosis [1-3]. Initial binding of $\mathrm{gD}$ to its cognate receptors including nectin-1, herpesvirus entry mediator (HVEM), and other receptors [4-9] is thought to trigger sequential conformational changes first in $\mathrm{gD}$ and then in $\mathrm{gH} / \mathrm{gL}$ and ultimately $\mathrm{gB}$ that results in fusion of the viral envelope with cellular membranes during virus entry as well as fusion among cellular membranes [10-14]. Specifically, initial attachment of the virus to cellular membranes is mediated by interaction of glycoproteins $\mathrm{gB}$ and $\mathrm{gC}$ with glycosaminoglycan (GAG) moieties of cell surface proteoglycans $[15,16]$. Subsequently, viral glycoprotein $\mathrm{gD}$ binds with one or more of its specific receptors, including the HVEM (HveA), nectin-1 (HveC), or 3-O-sulfated heparan sulfate [5-7]. gB can also bind to additional receptors (coreceptors), including paired immunoglobulin-like type 2 receptor alpha (PILR $\alpha$ ), non-muscle myosin heavy chain IIA (NMHC-IIA), and myelin-associated glycoprotein (MAG), that play a pivotal role in virion attachment and virus entry [17-19].

Although $\mathrm{gB}$ is the sole fusogenic viral glycoproteinmediating membrane fusion of the viral envelope with cellular membranes during virus entry as well as virus-induced cell-tocell fusion that facilitates virus spread, viral glycoproteins $\mathrm{gH}$, $\mathrm{gL}$, and $\mathrm{gK}$ play accessory roles in controlling gB-mediated membrane fusion $[13,20]$. Virions that lack $\mathrm{gK}$ enter into green African monkey kidney cells (Vero), albeit with lower efficiency than the wild-type virus [21,22]. Deletion of amino acids 31-68 within the amino terminus of gK inhibits virusinduced cell-to-cell fusion and virus entry without drastically inhibiting virion envelopment and egress [20,22]. Of particular interest is $\mathrm{gK}$, which contains determinants that are required for successful infection of neuronal axons. Specifically, a recombinant virus lacking gK amino acids 31-68 replicated fairly efficiently in all cell types, while it was unable to establish latency after ocular infection of mouse eyes [23]. Recent experiments have shown that the $\mathrm{gK} \Delta 31-68$ mutation prevents the virus from entering into axonal compartments of neurons in cell culture (manuscript, submitted).

After fusion of the viral envelope with the host plasma membrane, the tegumented capsids containing the viral genome are released into the cytosol and are transported via the microtubular network in a retrograde manner towards the nuclei of infected cells facilitated via the dynein-dynactin motor complex, which attaches tegumented capsids to microtubules [24-26]. The dynein-dynactin motor complex is utilized for the intracellular transport of other viruses including vaccinia virus and adenovirus [27-31].

HSV-1 and HSV-2 Pathogenesis HSV-1 and HSV-2 are closely related viruses with viral genomes exhibiting $83 \%$ nucleotide identity [32]. However, these viruses cause different disease symptoms. HSV-1 causes cold sores, herpetic whitlow, encephalitis, herpes ocular infections, and keratitis [33-35], and it is the leading cause of infectious blindness in the USA $[36,37]$. HSV-2 is primarily a sexually transmitted disease with high global prevalence, and the disease is primarily restricted to the genitals [38]. Seroprevalence studies have indicated that one of two adults in the USA aged 14-49 years old is infected with HSV-1 in a latent state [39]. HSV-1 has been increasingly identified as the cause of clinical genital herpes infections [40-42]. Infected individuals typically experience frequent but asymptomatic viral reactivation from latency, resulting in virus shedding that contributes to high transmission rates [43-45]. Both HSV-1 and HSV-2 produce persistent lifelong infections by establishing latency in immune-privileged sensory neurons [46]. Herpes infections can carry significant social implications, and the economic costs associated with genital herpes is substantial (projected to be around $\$ 2.5$ billion in 2015 and around $\$ 3$ billion in 2025) [47]. Importantly, genital HSV infection is considered a risk factor for acquiring human immunodeficiency virus infection [48-56] and, in some geographical areas, HSV-2 infection may be a contributing factor to $30-50 \%$ of new HIV infections [49, 57]. A successful vaccination strategy against HSV-2 infection is predicted to have a dramatic global impact on HIV spread and prevention of genital clinical disease and neonatal infections [58-60].

Immune Responses Prior HSV infection appears to partially protect against re-infections and may decrease clinical disease symptoms including frequency of viral reactivation [43, 61]. Primary infection can induce strong humoral and cellular immune responses that contribute to controlling subsequent infections. The production of neutralizing antibodies is thought to play an important role in limiting virus spread [62-64]. However, adapted cellular immune responses exerted at mucosal sites of viral infection (ocular, genital) are crucial in controlling HSV infections as well as reactivation of the virus from latently infected ganglionic neurons [65-71].

Innate Immune Responses Virion particles are initially detected by pattern recognition receptors (PRRs) that recognize pathogen-associated molecular patterns (PAMPs) including viral antigens and viral DNA and RNA. As is the case with many infectious agents, innate immune responses mediated by macrophages, neutrophils, and other innate immune cells confer immediate nonspecific protection against HSV-2 [72]. Moreover, elicitation of the appropriate innate immune response may be required for the induction of downstream humoral and cellular immune responses. Glycoprotein $\mathrm{gB}$ binds Toll-like receptor 2 (TLR-2) and alters downstream signaling, which may be used for immune evasion purposes [73]. Other Toll-like receptors including TLR9 [74], TLR3 [75], and 
TLR5 [76] appear to be involved in the immune response against HSVs.

Humoral Immune Responses Although preclinical studies have indicated that strong humoral responses may limit viral spread and disease symptoms, experimental infections in animals have also shown that B cells were dispensable with relation to clearance of HSV-2 infection [77] and human clinical trials of certain vaccines have failed despite the generation of strong humoral responses against the virus [78, 79]. Other experiments have shown that humoral responses may contribute to disease protection [62, 80-83]. A replication-defective HSV-2 lacking gD2 was able to protect mice against lethal genital HSV-2 challenge. This vaccine produced very weak neutralizing antibodies against the challenging virus; however, serum from vaccinated animals was able to passively protect naïve mice from challenge. The serum displayed potent antibody-dependent cellular cytotoxicity properties targeting antigens other than gD2 [84]. Collectively, it is highly probable that humoral responses play a significant role in limiting HSV viral infections and associated clinical symptoms.

Cellular Immune Responses Extensive work in experimental animals has provided strong evidence that induction of both HSV-specific $\mathrm{CD} 4^{+} \mathrm{T}$ cells and $\mathrm{CD} 8^{+} \mathrm{T}$ cells are required for maximum protection $[69,77]$. Data from subsequent studies indicate that $\mathrm{CD} 8^{+}$tissue-resident $\mathrm{T}$ cells may protect against HSV-2-reactivated virus in human peripheral tissues [85]. The importance of tissue-specific memory immune responses is underscored in a recent study that has utilized a "prime-pull" immunogenicity approach consisting of initial parenteral vaccination to induce systemic $\mathrm{T}$ cell response followed by intravaginal chemokine application to enhance recruitment of activated $\mathrm{T}$ cells to genital tissues [86]. Several studies have also implicated the involvement of regulatory $\mathrm{T}$ cells (Tregs) in the control of HSV-2 infections, since in Tregdeprived mice, dendritic and T cells appeared to migrate more slowly into infected tissues and interferon levels were lower in the draining lymph nodes [74].

Vaccine Approaches Many vaccine approaches and candidate vaccines have been tested in laboratory animals and humans including purified peptides; recombinant glycoprotein subunits; inactivated, live-attenuated, replicationcompetent and replication-defective whole virus; as well as DNA-based vaccines administered via different routes of immunization (reviewed in [59, 87-92]). A detailed chronological list of published papers during the last 5 years is provided in Table 1, and certain distinct vaccine approaches are described below.

Subunit and Peptide Vaccines Subunit vaccines are the most studied HSV-2 vaccines; however, to date, none have conferred protective immune responses against HSV-2 infections in clinical trials [135]. Viral glycoproteins $\mathrm{gB}$ and $\mathrm{gD}$ that can elicit both humoral and cellular immune responses have been favored as subunit vaccines. A gD2 subunit vaccine with an alum/MPL adjuvant reduced HSV-2 disease in HSV2-seronegative women but had no apparent benefit against genital herpes in men and HSV-1-seropositive women [136]. A subsequent double-blind, controlled, randomized efficacy field trial of a HSV-2 glycoprotein D (gD-2) subunit vaccine (Herpevac Trial) in 8323 women showed that the vaccine was $82 \%$ protective against HSV- 1 genital disease but offered no significant protection against HSV-2 genital disease [79]. Antiviral protection correlated with induction of neutralizing antibody against gD-2, while cellular immune responses did not appear to play an important role in conferring protection $[137,138]$.

Newer vaccine approaches utilize libraries of $B$ and $T$ cell epitope peptides in conjunction with newer adjuvant formulations that are specifically targeted to elicit strong humoral and cellular immune responses. An example of this approach is the use of T cell epitopes derived from the ICP4 protein and antibody generated by the gD2 glycoprotein in conjunction with the proprietary adjuvant Matrix-M (reviewed in [88]) (Table 2, GEN-003). Recently, it was recognized that $\mathrm{T}$ cells from symptomatic and asymptomatic patients target different epitopes, leading to the hypothesis that elicitation of the appropriate $\mathrm{B}$ and $\mathrm{T}$ cell responses may provide protection [139]. A vaccine approach based on this principle (HerpV) generated $\mathrm{CD}^{+}$and $\mathrm{CD}^{+} \mathrm{T}$ cell responses in mice and in HSV-2seropositive human patients [140, 141] (Table 2).

DNA and Viral-Vectored Vaccines DNA vaccine vectors expressing gD2 and gB2 genes have shown an ability to elicit protective immune responses in preclinical studies. A DNAbased gD2 vaccine has been shown to elicit cellular immune responses in a double-blind, vehicle-controlled, dose escalation safety, and immunogenicity trial [142]. However, it is unlikely that this type of vaccine approach will find wide use, since typically multiple vaccinations are needed over a prolonged period of time to elicit significant immune responses. HSV viral antigens also have been expressed via a variety of viral vectors including adenoviruses and vaccinia virus that can induce strong adjuvant-like responses in experimental animals and humans. Specifically, the modified vaccinia virus Ankara (MVA) has been used to express HSV-2 $\mathrm{gD}$, inducing strong cellular and humoral immunity [143].

Live-Attenuated Virus Vaccines In principle, live-attenuated vaccines have distinct advantages over subunit and inactivated vaccines, primarily because replication of the pathogen allows for the entire repertoire of pathogen-specific antigen expression. Given the $83 \%$ nucleotide identity shared by both HSV1 and HSV-2 genomes [32], cross-protective immunity may 
Table 1 Past 5 years of preclinical HSV vaccine development

\begin{tabular}{|c|c|c|c|c|c|c|}
\hline Type & Description & Adjuvant & Animal model & $\begin{array}{l}\text { Route of } \\
\text { challenge }\end{array}$ & Year & Reference \\
\hline Epitope & $\mathrm{gD} 2_{53-61}, \mathrm{gD} 2_{70-78}, \mathrm{gD} 2_{278-286}, \mathrm{gD} 2_{287-317}$ & $N$-Palmitoyl-lysine & Rabbit & Ocular & 2015 & {$[93 \cdot]$} \\
\hline Epitope & $\begin{array}{l}\text { HSV-1 VP11/12 } \\
\text { VP11/12-74, VP11/12 } 2220-228,\end{array}$ & $\mathrm{CpG}$ & Mouse & Ocular & 2015 & [94] \\
\hline Replication defective & HSV-2 DeltagD $(-/+\mathrm{gD} 1)$ & NA & Mouse & Genital & 2015 & {$[84]$} \\
\hline Replication defective & HSV-2 HSV529 & NA & Guinea pig/mouse & Genital & 2015 & {$[95]$} \\
\hline Live attenuated & HSV-2 ICP0(-) virus, 0DeltaNLS & NA & Mouse & Genital & 2015 & {$[96]$} \\
\hline Recombinant virus & HPV-gBsec, HPV-gDsec, HPV-gBsec/gDsec & NA & Mouse & Genital & 2015 & [97] \\
\hline Live attenuated & HSV-1 KOS-63 & NA & Mouse & Ocular & 2014 & [98] \\
\hline Live attenuated & HSV-1 HSV-CD80 & NA & Mouse & NA & 2014 & [99] \\
\hline Subunit & $\mathrm{gG} 2$ & CpG/alum & Mouse & Genital & 2014 & {$[100]$} \\
\hline Subunit & $\mathrm{gD} 2, \mathrm{gD} 2 / \mathrm{gC} 2$ & CpG/alum, MPL/alum & Guinea pig & Genital & 2014 & {$[101]$} \\
\hline Subunit & $\mathrm{gD} 2, \mathrm{gE} 2 / \mathrm{gC} 2 / \mathrm{gD} 2$ & CpG/alum & Mouse & Genital & 2014 & {$[102]$} \\
\hline Replication defective & HSV-2 CJ2-gD2 & NA & Guinea pig & Genital & 2014 & [103] \\
\hline Live attenuated & HSV-2 UL24 mutant & NA & Guinea pig/mouse & Genital & 2014 & {$[104]$} \\
\hline Live attenuated & HSV-1 VC2 & NA & Mouse & Genital & 2014 & {$[105 \bullet \bullet]$} \\
\hline Live attenuated & HSV-1 encoding the HIV-1 Tat & NA & Mouse & Genital & 2014 & {$[106]$} \\
\hline Live attenuated & HSV-2 TK(-) & NA & Mouse & Genital & 2014 & {$[107]$} \\
\hline Epitope & $\mathrm{gB}_{342-350}, \mathrm{gB} 1_{561-569}, \mathrm{gB} 1_{183-191}, \mathrm{gB} 1_{441-449}$ & $\mathrm{CpG}$ & Mouse & Ocular & 2013 & {$[108]$} \\
\hline DNA & pIRES I and pIRES II & NA & Mouse & Nasal & 2013 & [109] \\
\hline Other & DC/HSV-1 & NA & Mouse & IP, ear & 2013 & {$[110]$} \\
\hline Replication defective & HSV-1 $\Delta \mathrm{gK}$ & NA & Mouse & Genital & 2013 & {$[111]$} \\
\hline Live attenuated & $\begin{array}{l}\text { Wild-type HSV-2, HSV-2 ICP0 (-) viruses } \\
\text { (0Delta254, 0Delta810, 0DeltaRING, or } \\
\text { 0DeltaNLS) }\end{array}$ & NA & Guinea pig & Genital & 2013 & {$[81]$} \\
\hline DNA & $\begin{array}{l}\text { Ubiquitinated and non-ubiquitinated constructs } \\
\text { encoding gD }\end{array}$ & NA & Mouse & Genital & 2013 & [112] \\
\hline Other & DTK-NISV, gB1s-NISV & NA & Mouse & Genital & 2013 & {$[113]$} \\
\hline Live attenuated & HSV2-gD27 & NA & Mouse & NA & 2012 & {$[114]$} \\
\hline Subunit & $\mathrm{gD} 2$ & IC31((R)) & Mouse & Genital & 2012 & [115] \\
\hline Replication defective & HSV-2 ACAM529 & NA & Mouse & Genital & 2012 & [116] \\
\hline Live attenuated & HSV-2 gE2-del & NA & Guinea pig/mouse & Genital & 2012 & [117] \\
\hline Recombinant virus & Lipo/rAdv5 & NA & Mouse & Genital & 2012 & [118] \\
\hline Replication defective & HSV-1 ICP8(-)vhs(-) and ICP8(-)vhs(-)B7 & NA & Mouse & Ocular & 2011 & [119] \\
\hline DNA & pRSC-gD-IL-21 & NA & Mouse & Ocular & 2011 & {$[120]$} \\
\hline DNA & pRSC-gD-IL-21 & NA & Mouse & Ocular & 2011 & {$[121]$} \\
\hline DNA & pcgB, pcEpitope & NA & Mouse & NA & 2011 & {$[122]$} \\
\hline Subunit & $\begin{array}{l}\mathrm{gD} 2 \text {, truncated gD2t, gD2/gB2/gH2/gL2, } \\
\mathrm{gB} 2 / \mathrm{gH} 2 / \mathrm{gL} 2\end{array}$ & CLDC & Guinea pig & Genital & 2011 & [123] \\
\hline Subunit & $\mathrm{gD} 2, \mathrm{gB} 2, \mathrm{gD} 2 / \mathrm{gB} 2$ & CpG/alum & Guinea pig/mouse & Genital & 2011 & {$[124]$} \\
\hline Subunit & $\mathrm{gC} 2 / \mathrm{gD} 2$ & CpG/alum & Guinea pig/mouse & Genital & 2011 & {$[125]$} \\
\hline Epitope & $\begin{array}{l}\mathrm{gB} 2_{466-473}, \mathrm{gC} 2_{216-223}, \mathrm{gD} 2_{6-18}, \mathrm{gE} 2_{483-491} \\
\mathrm{gG} 2_{572-579}, \mathrm{gI} 2_{286-295}, \mathrm{gD} 2_{21-28}, \mathrm{gB} 2_{162-177} \\
\mathrm{gD} 2_{205-224}, \mathrm{gD} 2_{245-259}, \mathrm{gD} 2_{10-20}, \mathrm{gD} 2_{268-276}\end{array}$ & Freund's adjuvant & Mouse & Genital & 2011 & {$[126]$} \\
\hline Live attenuated & HSV-2 ICP0(-) virus, 0DeltaNLS & NA & Mouse & Genital & 2011 & {$[127]$} \\
\hline DNA & gD DNA vaccine & NA & Mouse & Genital & 2011 & [128] \\
\hline DNA & pVAX-FI-HSV2 & NA & Guinea pig & Genital & 2011 & [129] \\
\hline Other & pcDNA3-gD phagemid particles & NA & Mouse & NA & 2010 & [130] \\
\hline Subunit & $\mathrm{gD} 2$ & CLDC, MPL/alum & Guinea pig & Genital & 2010 & [131] \\
\hline Replication defective & HSV-2 dl5-29, dl5-29-41, dl5-29-41.1 & NA & Mouse & Genital & 2010 & [132] \\
\hline Live attenuated & & NA & Mouse & Genital & 2010 & [133] \\
\hline
\end{tabular}


Table 1 (continued)

\begin{tabular}{llllll}
\hline Type & Description & Adjuvant & Animal model & $\begin{array}{c}\text { Route of } \\
\text { challenge }\end{array}$ & $\begin{array}{c}\text { Year } \\
\text { Reference }\end{array}$ \\
\hline & $\begin{array}{l}\text { wild-type HSV-2, HSV-2 ICP0 (-) viruses } \\
\text { (0Delta254, 0Delta810, 0DeltaRING, or } \\
\text { 0DeltaNLS) } \\
\text { Nanopatch+DNA vaccine }\end{array}$ & NA & & & \\
DNA & & Mouse & Genital & 2010 & {$[134]$} \\
\hline
\end{tabular}

Table 2 Current clinical trials of HSV vaccines

\begin{tabular}{llccc}
\hline Intervention & Company & Trial & Info & $\begin{array}{l}\text { ClinicalTrials.gov } \\
\text { identifier }\end{array}$ \\
\hline
\end{tabular}

Replication-defective HSV529 Sanofi Pasteur Ongoing phase 1 The trial, being conducted at the National Institutes

NCT01915212 of Health Clinical Center, is utilizing healthy adults aged 18-40 years and consist of 3 vaccination visits with 7 follow-up visits. Participants will be screened with a medical history and physical exam. The study has an estimated completion date of January 2030

\author{
HerpV polyvalent peptide \\ complex adjuvanted \\ with QS-21
}

Agenus Completed phase 2

Enrolle a history of $1-9$ herpes episodes within the prior
. 12 -month period. Treatment consisted of 3 injections of HerpV at a dose of $240 \mu \mathrm{g}$ in 2-week intervals. Results published in a press release showed that vaccination with HerpV demonstrated a significant reduction in viral shedding $(P=0.015 ; \mathrm{RR}=0.85)$. These results suggest a $15 \%$ reduction in viral shedding and a $34 \%$ reduction in viral load $(P=0.08)$

GEN-003 is a subunit vaccine $\quad$ Genocea
comprised of HSV-2
glycoprotein $\mathrm{D} 2$
$\left(\mathrm{gD} 2 \Delta \mathrm{TMR}_{340-363)}\right.$ ) and
infected cell polypeptide 4
(ICP4 $4_{383-766}$ ) adjuvanted with
proprietary Matrix-M2

VCL-HB01 plasmid-based vaccine Vical encoding two HSV-2 proteins and VCL-HM01 plasmid-based vaccine encoding one HSV-2 protein, both adjuvanted with Vaxfectin

\section{Ongoing phase} $1 /$ phase 2
Press release of results from the phase $1 / 2$ a clinical trial demonstrated that during a 28-day observation period 6 months after administration of GEN-003 patients that received $30 \mu \mathrm{g}$ doses presented a $65 \%$ reduction in genital lesion occurrence, significantly less than baseline $(P<0.001)$. Observations collected again 12 months after vaccination demonstrated a $42 \%$ reduction on lesion formation and significantly elevated humoral and cellular immune responses. The phase 2 study consists of 310 subjects from 17 institutions in the USA. Topline results which identified an optimal dose of $60 \mu \mathrm{g}$ per protein/75 $\mu \mathrm{g}$ of Matrix-M2 adjuvant demonstrated a highly statistically significant $(P<0.0001) 55 \%$ reduction from baseline in the viral shedding rate, the primary endpoint of the trial and a measure of anti-viral activity

A press release has stated that Vical has completed enrollment in its clinical study, and the randomized, double-blind, placebo-controlled trial will evaluate safety, tolerability, and efficacy of two vaccine candidates (one encoding glycoprotein $\mathrm{D}$ alone and the other in combination with UL46). The study is powered to show at least a $30 \%$ decrease in the viral shedding rate following 3 doses of vaccine. A total of 165 otherwise healthy HSV-2-infected patients aged 18 to 50 years were enrolled across seven US trial sites. The company expects to release efficacy data in the middle of 2015
NCT02114060 
be achieved by a single safe and efficacious vaccine expressing a large enough repertoire of cross-protective antigens. Attempts at generating a live-attenuated HSV vaccine have focused on the preparation of attenuated viruses that can generate robust immune responses while minimizing potential virulence in the host. Generally, the entire genes that play important roles in the virus life cycle have been deleted or otherwise modified to attenuate the virus and allow a more robust production of humoral and cellular immune responses. Viral genome modifications include deletions in glycoprotein $\mathrm{E}(\mathrm{gE})$ [117, 144]; multiple deletions in $\gamma 34.5$, UL55-56, UL43.5, and US10-12 genes [145] and in UL5, UL29, UL41, and ICP27 genes [146-149]; deletion of ICP0 [127, 133] and UL9 genes [150-153]; and deletion of $\mathrm{gD}$ [84]. Other live virus vaccines under study include the HSV-1 virus CJ9-gD engineered to overexpress gD1 and having a dominant negative mutation to prevent virus replication. This vaccine strain has been reported to protect guinea pigs from HSV-2 intravaginal challenge, with marked reduction in vital titer and lesion formation [152]. These vaccine approaches face two major hurdles that need to be overcome before they can be successfully applied to human patients: (1) replicationdefective viruses typically require growing the virus in a complementing cell line adding to the complexity of producing the vaccine as well as associated safety and regulatory issues associated with the validation of the cell line that is used to grow the virus and (2) all viruses, regardless of the specific gene deletions, are capable of entering into neurons and may establish latency as well as potentially recombine with endogenous HSVs. To circumvent this potential safety issue, a recombinant virus carrying specific mutations in $\mathrm{gD} 2$ that prevent the virus for binding to its neuronal receptor nectin-1 was recently constructed and shown to protect mice against HSV-2 infection, while the vaccine virus did not enter into ganglionic neurons [114]. However, these single-amino acid changes in $\mathrm{gD}$ can revert in vivo to produce a wild-type-like virus with pathogenic potential.

Initial experiments with live-attenuated vaccination of human patients with a HSV-2 mutant virus, which is deleted in the PK domain of the large subunit of ribonucleotide reductase (ICP10DeltaPK) [154], revealed that only a fraction of the vaccinated individuals were significantly protected against viral reactivation and subsequent clinical symptoms [155]. Similarly, a virus having the $\mathrm{gH}$ gene deleted revealed no significant benefit against HSV-2 infection in immunocompetent men and women [156]. A current clinical trials involves the testing of replication-defective HSV529, a vaccine version derived from mutant virus d15-29 virus having the UL29 (ICP8) and UL5 (component of the viral helicase-primase), which has been shown to induce protective immune responses in mice and guinea pigs [95, 132]. However, deletion of the UL29 and UL5 genes will not prevent virus entry into neurons and establishment of latency. Current clinical trials with various vaccine approaches are listed in Table 2.

Generation of a safe and effective replication-competent HSV-1 virus is important to not only vaccinate against acquiring HSV infection and reduce HIV prevalence, but also a safe vaccine vector could be utilized for expression of heterologous antigens from other pathogens. HSV has many nonessential genes and can stably carry large fragments of foreign DNA. This genetic flexibility is ideal for the expression of antigens specific to other pathogens $[157,158]$. The recombinant HSV-1 talimogene laherparepvec (Amgen, Inc.) expressing granulocyte monocyte colony-stimulating factor (GMCSF), a potent chemokine functioning in the maturation of macrophages, has been used in combination with other chemotherapeutics for the treatment of squamous cell cancer of the head and neck with promising phase I/II results [159]. In addition, this vaccine improved durable response rate in patients with advanced melanoma in a phase III clinical trial [160 ]. FDA approval of talimogene laherparepvec for melanoma therapy is expected to pave the way for the use of liveattenuated HSV-based vectors for vaccination against HSV and other pathogens.

\section{Lessons Learned from the Live-Attenuated VZV Vaccine} Strain The VZV alphaherpesvirus causes varicella (chickenpox) during primary infections followed by establishment of latency in dorsal ganglionic neurons. Reactivation of the virus causes herpes zoster (HZ), commonly referred to as shingles. The currently used Oka vaccine strain of VZV was isolated from a healthy Japanese child with varicella and attenuated by serial passage in cell culture. The vaccine was initially tested for a number of years in Japan and later gained FDA approval for use in Europe and the USA. The vaccine has been proven to be safe and provide significant clinical efficacy in immunocompetent individuals, while it was shown to boost VZV-specific cell-mediated immune responses in both immunocompetent and immunocompromised adults. Routine childhood immunization has markedly reduced the incidence of varicella in the USA [161-164].

Development of the HSV-1 VC2 Vaccine Strain Previously, we have shown that a HSV-1 gK-null virus was unable to infect ganglionic neurons and establish latency after ocular infection of mice $[165,166]$. Recently, we capitalized on the attenuated properties of the gK-null virus and showed that intramuscular vaccination of mice with the gK-null virus conferred significant cellular immune responses and protection against intravaginal challenge of mice with either virulent HSV-1(McKrae) or HSV-2(G) viruses [111]. To further improve this vaccination approach, we constructed the $\mathrm{VC} 2 \mathrm{mu}-$ tant virus with specific deletions within the genes coding for glycoprotein $\mathrm{K}(\mathrm{gK})$ and UL20. The VC2 virus contains the $\mathrm{gK} \Delta 31-68$ mutation that prevents the virus from infecting 
ganglionic neurons after ocular infection in mice [167]. In contrast to the gK-null virus that requires replication in the complementing cell line VK302 that expresses gK, the VC2 virus can replicate efficiently in infected Vero cells, achieving titers similar to those of the wild-type HSV-1(F) parental virus in cell culture $[105 \bullet, 111]$. A single intramuscular vaccination with the VC2 virus was very well tolerated at a high infectious dose $\left(10^{7} \mathrm{PFU}\right)$, produced a robust humoral and cell-mediated immune response, and conferred $100 \%$ protection against lethal intravaginal challenge with either HSV-1 (McKrae) or HSV-2 (G) viruses [105••].

Amelioration of herpetic eye disease can be augmented either prophylactically or therapeutically by a robust antiHSV immune response [93•, 94, 108, 119-121] (Table 1). Specifically, an asymptomatic individual's immune system recognizes a different repertoire of HSV antigens than those of a symptomatic individual [168-170]. Alteration of these antigenic recognition patterns within target HSV proteins must be induced during the primary insult of infection. $\mathrm{VC} 2$ exhibits distinctly different innate recognitions when compared to the parental virus HSV-1(F) strain and can protect against lethal ocular infection of mice, suggesting that $\mathrm{gK}$ is involved in immune evasion (unpublished). This altered innate recognition of the $\mathrm{VC} 2$ virus may serve as a stimulus for significantly altered epitope recognition in the downstream adaptive immune response, resulting in enhanced immune responses against HSV-1 and HSV-2 ocular and genital infections.

\section{Conclusions}

Based on the successful deployment of the VZV liveattenuated vaccine, it is likely that a similar approach could be used to produce an efficacious live-attenuated HSV vaccine provided that safety concerns are resolved. Preclinical results with the VC2 vaccine are particularly encouraging. The VC2 vaccine, unlike other live-attenuated viral strains, cannot enter into neuronal axons and elicits stronger humoral and cellular immune responses than its parental HSV-1(F) strain, indicating that the specific modifications of the VC2 $\mathrm{gK}$ and UL20 proteins alter the canonical signaling pathways that ultimately produce robust humoral and cellular immune responses. Understanding immune evasion mechanisms mediated by gK and UL20 in conjunction with other viral glycoproteins may provide improved versions of the VC2 vaccine strain that can elicit strong, tissue-specific protective $\mathrm{B}$ and $\mathrm{T}$ cell responses. Also, VC2 could serve as a vector platform for the production of vaccines against other viral and bacterial infections.

Acknowledgments We acknowledge the support by the Louisiana Board of Regents, the LSU School of Veterinary Medicine, and the
LSU Center for Experimental Infectious Disease Research (CEIDR) supported by NIH:NIGMS P30 GM110760. We thank Dr. Rider and the members of the BioMMED staff for their assistance with the manuscript.

\section{Compliance with Ethics Guidelines}

Conflict of Interest Dr. Kousoulas and B. Stanfield report that a patent application on the $\mathrm{VC} 2$ vaccine is pending.

Human and Animal Rights and Informed Consent This article contains no studies with human or animal subjects performed by the author.

\section{References}

Papers of particular interest, published recently, have been highlighted as:

- Of importance

• Of major importance

1. Nicola AV, Hou J, Major EO, Straus SE. Herpes simplex virus type 1 enters human epidermal keratinocytes, but not neurons, via a $\mathrm{pH}$-dependent endocytic pathway. J Virol. 2005;79(12): 7609-16.

2. Qie L, Marcellino D, Herold BC. Herpes simplex virus entry is associated with tyrosine phosphorylation of cellular proteins. Virology. 1999;256(2):220-7.

3. Milne RS, Nicola AV, Whitbeck JC, Eisenberg RJ, Cohen GH. Glycoprotein D receptor-dependent, low-pH-independent endocytic entry of herpes simplex virus type 1 . J Virol. 2005;79(11):6655-63.

4. Campadelli-Fiume G, Cocchi F, Menotti L, Lopez M. The novel receptors that mediate the entry of herpes simplex viruses and animal alphaherpesviruses into cells. Rev Med Virol. 2000;10(5):305-19.

5. Geraghty RJ, Krummenacher C, Cohen GH, Eisenberg RJ, Spear PG. Entry of alphaherpesviruses mediated by poliovirus receptorrelated protein 1 and poliovirus receptor. Science. 1998;280(5369):1618-20.

6. Montgomery RI, Warner MS, Lum BJ, Spear PG. Herpes simplex virus-1 entry into cells mediated by a novel member of the TNF/ NGF receptor family. Cell. 1996;87:427-36.

7. Shukla D, Liu J, Blaiklock P, Shworak NW, Bai X, Esko JD, et al. A novel role for 3-O-sulfated heparan sulfate in herpes simplex virus 1 entry. Cell. 1999;99(1):13-22.

8. Spear PG, Eisenberg RJ, Cohen GH. Three classes of cell surface receptors for alphaherpesvirus entry. Virology. 2000;275(1):1-8.

9. Spear PG, Longnecker R. Herpesvirus entry: an update. J Virol. 2003;77(19):10179-85.

10. Hannah BP, Heldwein EE, Bender FC, Cohen GH, Eisenberg RJ. Mutational evidence of internal fusion loops in herpes simplex virus glycoprotein B. J Virol. 2007;81(9):4858-65.

11. Heldwein EE, Lou H, Bender FC, Cohen GH, Eisenberg RJ, Harrison SC. Crystal structure of glycoprotein B from herpes simplex virus 1. Science. 2006;313(5784):217-20.

12. Connolly SA, Jackson JO, Jardetzky TS, Longnecker R. Fusing structure and function: a structural view of the herpesvirus entry machinery. Nat Rev Microbiol. 2011;9(5):369-81.

13. Atanasiu D, Saw WT, Cohen GH, Eisenberg RJ. Cascade of events governing cell-cell fusion induced by herpes simplex virus glycoproteins gD, gH/gL, and gB. J Virol. 2010;84(23):12292-9. 
14. Atanasiu D, Whitbeck JC, Cairns TM, Reilly B, Cohen GH, Eisenberg RJ. Bimolecular complementation reveals that glycoproteins $\mathrm{gB}$ and $\mathrm{gH} / \mathrm{gL}$ of herpes simplex virus interact with each other during cell fusion. Proc Natl Acad Sci U S A. 2007;104(47): 18718-23.

15. Herold BC, WuDunn D, Soltys N, Spear PG. Glycoprotein C of herpes simplex virus type 1 plays a principal role in the adsorption of virus to cells and in infectivity. J Virol. 1991;65(3):1090-8.

16. Shukla D, Spear PG. Herpesviruses and heparan sulfate: an intimate relationship in aid of viral entry. J Clin Invest. 2001;108(4): 503-10.

17. Satoh T, Arii J, Suenaga T, Wang J, Kogure A, Uehori J, et al. PILRalpha is a herpes simplex virus-1 entry coreceptor that associates with glycoprotein B. Cell. 2008;132(6):935-44.

18. Arii J, Goto H, Suenaga T, Oyama M, Kozuka-Hata H, Imai T, et al. Non-muscle myosin IIA is a functional entry receptor for herpes simplex virus-1. Nature. 2010;467(7317):859-62.

19. Suenaga T, Satoh T, Somboonthum P, Kawaguchi Y, Mori Y, Arase H. Myelin-associated glycoprotein mediates membrane fusion and entry of neurotropic herpesviruses. Proc Natl Acad Sci U S A. 2010;107(2):866-71.

20. Chouljenko VN, Iyer AV, Chowdhury S, Chouljenko DV, Kousoulas KG. The amino terminus of herpes simplex virus type 1 glycoprotein $\mathrm{K}(\mathrm{gK})$ modulates gB-mediated virus-induced cell fusion and virion egress. J Virol. 2009;83(23):12301-13.

21. Foster TP, Rybachuk GV, Kousoulas KG. Glycoprotein K specified by herpes simplex virus type 1 is expressed on virions as a Golgi complex-dependent glycosylated species and functions in virion entry. J Virol. 2001;75(24):12431-8.

22. Jambunathan N, Chowdhury S, Subramanian R, Chouljenko VN, Walker JD, Kousoulas KG. Site-specific proteolytic cleavage of the amino terminus of herpes simplex virus glycoprotein $\mathrm{K}$ on virion particles inhibits virus entry. J Virol. 2011;85(24):12910-8.

23. Saied AA, Chouljenko VN, Subramanian R, Kousoulas KG. A replication competent HSV-1(McKrae) with a mutation in the amino-terminus of glycoprotein $\mathrm{K}(\mathrm{gK})$ is unable to infect mouse trigeminal ganglia after cornea infection. Curr Eye Res. 2014;39(6):596-603.

24. Mettenleiter TC, Klupp BG, Granzow H. Herpesvirus assembly: an update. Virus Res. 2009;143(2):222-34.

25. Johnson DC, Baines JD. Herpesviruses remodel host membranes for virus egress. Nat Rev Microbiol. 2011;9(5):382-94.

26. Diefenbach RJ, Miranda-Saksena M, Douglas MW, Cunningham AL. Transport and egress of herpes simplex virus in neurons. Rev Med Virol. 2008;18(1):35-51.

27. Greber UF, Way M. A superhighway to virus infection. Cell. 2006;124(4):741-54.

28. Dohner K, Wolfstein A, Prank U, Echeverri C, Dujardin D, Vallee $\mathrm{R}$, et al. Function of dynein and dynactin in herpes simplex virus capsid transport. Mol Biol Cell. 2002;13(8):2795-809.

29. Leopold PL, Kreitzer G, Miyazawa N, Rempel S, Pfister KK, Rodriguez-Boulan E, et al. Dynein- and microtubule-mediated translocation of adenovirus serotype 5 occurs after endosomal lysis. Hum Gene Ther. 2000;11(1):151-65.

30. Suomalainen M, Nakano MY, Keller S, Boucke K, Stidwill RP, Greber UF. Microtubule-dependent plus- and minus end-directed motilities are competing processes for nuclear targeting of adenovirus. J Cell Biol. 1999;144(4):657-72.

31. Sanderson CM, Hollinshead M, Smith GL. The vaccinia virus A27L protein is needed for the microtubule-dependent transport of intracellular mature virus particles. J Gen Virol. 2000;81(Pt 1): 47-58.

32. Dolan A, Jamieson FE, Cunningham C, Barnett BC, McGeoch DJ. The genome sequence of herpes simplex virus type 2 . J Virol. 1998;72(3):2010-21.
33. Usatine RP, Tinitigan R. Nongenital herpes simplex virus. Am Fam Physician. 2010;82(9):1075-82.

34. Whitley RJ, Kimberlin DW, Roizman B. Herpes simplex viruses. Clin Infect Dis. 1998;26(3):541-53. quiz 54-5.

35. Whitley R. Herpes simplex viruses. In: Knipe D, Howley P, editors. Fields virology. Philadelphia: Lippincott Williams and Wilkins; 2001. p. 2461-510.

36. Liesegang TJ, Melton 3rd LJ, Daly PJ, Ilstrup DM. Epidemiology of ocular herpes simplex. Incidence in Rochester, Minn, 1950 through 1982. Arch Ophthalmol. 1989;107(8):1155-9.

37. Liesegang TJ. Herpes simplex virus epidemiology and ocular importance. Cornea. 2001;20(1):1-13.

38. Gupta R, Warren T, Wald A. Genital herpes. Lancet. 2007;370(9605):2127-37.

39. Bradley H, Markowitz LE, Gibson T, McQuillan GM. Seroprevalence of herpes simplex virus types 1 and 2-United States, 1999-2010. J Infect Dis. 2014;209(3):325-33.

40. Mertz GJ, Rosenthal SL, Stanberry LR. Is herpes simplex virus type 1 (HSV-1) now more common than HSV-2 in first episodes of genital herpes? Sex Transm Dis. 2003;30(10):801-2.

41. Roberts CM, Pfister JR, Spear SJ. Increasing proportion of herpes simplex virus type 1 as a cause of genital herpes infection in college students. Sex Transm Dis. 2003;30(10):797-800.

42. Pereira VS, Moizeis RN, Fernandes TA, Araujo JM, Meissner RV, Fernandes JV. Herpes simplex virus type 1 is the main cause of genital herpes in women of Natal, Brazil. Eur J Obstet Gynecol Reprod Biol. 2012;161(2):190-3.

43. Hofstetter AM, Rosenthal SL, Stanberry LR. Current thinking on genital herpes. Curr Opin Infect Dis. 2014;27(1):75-83.

44. Tronstein E, Johnston C, Huang ML, Selke S, Magaret A, Warren $\mathrm{T}$, et al. Genital shedding of herpes simplex virus among symptomatic and asymptomatic persons with HSV-2 infection. J Am Med Assoc. 2011;305(14):1441-9.

45. Mertz GJ. Asymptomatic shedding of herpes simplex virus 1 and 2: implications for prevention of transmission. J Infect Dis. 2008;198(8):1098-100.

46. Pellet PE, Roizman B. The family Herpesviridae: a brief introduction. In: Fields BN, Knipe DM, Howley PM, editors. Fields' virology. 2. 5th ed. Philadelphia: Wolters Kluwer Health/Lippincott Williams \& Wilkins; 2007. p. 2480-99.

47. Fisman DN, Lipsitch M, Hook 3rd EW, Goldie SJ. Projection of the future dimensions and costs of the genital herpes simplex type 2 epidemic in the United States. Sex Transm Dis. 2002;29(10): 608-22.

48. Barnabas RV, Wasserheit JN, Huang Y, Janes H, Morrow R, Fuchs $\mathrm{J}$, et al. Impact of herpes simplex virus type 2 on HIV-1 acquisition and progression in an HIV vaccine trial (the Step study). J Acquir Immune Defic Syndr. 2011;57(3):238-44.

49. Freeman EE, Weiss HA, Glynn JR, Cross PL, Whitworth JA, Hayes RJ. Herpes simplex virus 2 infection increases HIV acquisition in men and women: systematic review and metaanalysis of longitudinal studies. AIDS. 2006;20(1):73-83. London, England

50. Horbul JE, Schmechel SC, Miller BRL, Rice SA, Southern PJ. Herpes simplex virus-induced epithelial damage and susceptibility to human immunodeficiency virus type 1 infection in human cervical organ culture. PLoS One. 2011;6(7):e22638.

51. Anuradha K, Singh HM, Gopal KV, Rama Rao GR, Ramani TV, Padmaja J. Herpes simplex virus 2 infection: a risk factor for HIV infection in heterosexuals. Indian J Dermatol Venereol Leprol. 2008;74(3):230-3.

52. Mugo N, Dadabhai SS, Bunnell R, Williamson J, Bennett E, Baya I, et al. Prevalence of herpes simplex virus type 2 infection, human immunodeficiency virus/herpes simplex virus type 2 coinfection, and associated risk factors in a national, population-based survey in Kenya. Sex Transm Dis. 2011;38(11):1059-66. 
53. Reynolds SJ, Risbud AR, Shepherd ME, Zenilman JM, Brookmeyer RS, Paranjape RS, et al. Recent herpes simplex virus type 2 infection and the risk of human immunodeficiency virus type 1 acquisition in India. J Infect Dis. 2003;187(10):1513-21.

54. Renzi C, Douglas Jr JM, Foster M, Critchlow CW, AshleyMorrow R, Buchbinder SP, et al. Herpes simplex virus type 2 infection as a risk factor for human immunodeficiency virus acquisition in men who have sex with men. J Infect Dis. 2003;187(1):19-25.

55. Wald A, Link K. Risk of human immunodeficiency virus infection in herpes simplex virus type 2-seropositive persons: a meta-analysis. J Infect Dis. 2002;185(1):45-52.

56. Sartori E, Calistri A, Salata C, Del Vecchio C, Palu G, Parolin C. Herpes simplex virus type 2 infection increases human immunodeficiency virus type 1 entry into human primary macrophages. Virol J. 2011;8:166.

57. Brown JM, Wald A, Hubbard A, Rungruengthanakit K, Chipato T, Rugpao $\mathrm{S}$, et al. Incident and prevalent herpes simplex virus type 2 infection increases risk of HIV acquisition among women in Uganda and Zimbabwe. AIDS. 2007;21(12):1515-23.

58. Freeman EE, White RG, Bakker R, Orroth KK, Weiss HA, Buve A, et al. Population-level effect of potential HSV2 prophylactic vaccines on HIV incidence in sub-Saharan Africa. Vaccine. 2009;27(6):940-6.

59. Johnston C, Koelle DM, Wald A. Current status and prospects for development of an HSV vaccine. Vaccine. 2014;32(14):1553-60.

60. Gottlieb SL, Low N, Newman LM, Bolan G, Kamb M, Broutet N. Toward global prevention of sexually transmitted infections (STIs): the need for STI vaccines. Vaccine. 2014;32(14):1527-35.

61. Blank H, Haines HG. Experimental human reinfection with herpes simplex virus. J Invest Dermatol. 1973;61(4):223-5.

62. Li Z, Palaniyandi S, Zeng R, Tuo W, Roopenian DC, Zhu X. Transfer of IgG in the female genital tract by MHC class Irelated neonatal $\mathrm{Fc}$ receptor $(\mathrm{FcRn})$ confers protective immunity to vaginal infection. Proc Natl Acad Sci U S A. 2011;108(11): 4388-93.

63. Morrison LA, Zhu L, Thebeau LG. Vaccine-induced serum immunoglobin contributes to protection from herpes simplex virus type 2 genital infection in the presence of immune T cells. J Virol. 2001;75(3):1195-204.

64. Seppanen M, Meri S, Notkola IL, Seppala IJ, Hiltunen-Back E, Sarvas H, et al. Subtly impaired humoral immunity predisposes to frequently recurring genital herpes simplex virus type 2 infection and herpetic neuralgia. J Infect Dis. 2006;194(5):571-8.

65. Koelle DM, Posavad CM, Barnum GR, Johnson ML, Frank JM, Corey L. Clearance of HSV-2 from recurrent genital lesions correlates with infiltration of HSV-specific cytotoxic T lymphocytes. J Clin Invest. 1998;101(7):1500-8.

66. Milligan GN, Bernstein DI, Bourne N. T lymphocytes are required for protection of the vaginal mucosae and sensory ganglia of immune mice against reinfection with herpes simplex virus type 2 . J Immunol. 1998;160(12):6093-100.

67. Schiffer JT, Corey L. Rapid host immune response and viral dynamics in herpes simplex virus-2 infection. Nat Med. 2013;19(3): 280-90.

68. Wakim LM, Jones CM, Gebhardt T, Preston CM, Carbone FR. CD8(+) T-cell attenuation of cutaneous herpes simplex virus infection reduces the average viral copy number of the ensuing latent infection. Immunol Cell Biol. 2008;86(8):666-75.

69. Zhu J, Koelle DM, Cao J, Vazquez J, Huang ML, Hladik F, et al. Virus-specific CD8+ T cells accumulate near sensory nerve endings in genital skin during subclinical HSV-2 reactivation. J Exp Med. 2007;204(3):595-603.

70. Dudley KL, Bourne N, Milligan GN. Immune protection against HSV-2 in B-cell-deficient mice. Virology. 2000;270(2):454-63.
71. St Leger AJ, Hendricks RL. CD8+ T cells patrol HSV-1-infected trigeminal ganglia and prevent viral reactivation. J Neurovirol. 2011;17(6):528-34.

72. Mark KE, Wald A, Magaret AS, Selke S, Kuntz S, Huang M-L, et al. Rapidly cleared episodes of oral and anogenital herpes simplex virus shedding in HIV-infected adults. J Acquir Immune Defic Syndr. 2010;54(5):482-8.

73. Reske A, Pollara G, Krummenacher C, Katz DR, Chain BM. Glycoprotein-dependent and TLR2-independent innate immune recognition of herpes simplex virus-1 by dendritic cells. J Immunol. 2008;180(11):7525-36.

74. Lund JM, Hsing L, Pham TT, Rudensky AY. Coordination of early protective immunity to viral infection by regulatory $\mathrm{T}$ cells. Science. 2008;320(5880):1220-4.

75. Zhu W, Zhao S, Liu Z, Cheng L, Wang Q, Yan K, et al. Pattern recognition receptor-initiated innate antiviral responses in mouse epididymal epithelial cells. J Immunol. 2015;194(10):4825-35.

76. Nazli A, Yao X-D, Smieja M, Rosenthal KL, Ashkar AA, Kaushic C. Differential induction of innate anti-viral responses by TLR ligands against herpes simplex virus, type 2, infection in primary genital epithelium of women. Antivir Res. 2009;81(2):103-12.

77. Lee AJ, Ashkar AA. Herpes simplex virus-2 in the genital mucosa: insights into the mucosal host response and vaccine development. Curr Opin Infect Dis. 2012;25(1):92-9.

78. Corey L, Langenberg AG, Ashley R, Sekulovich RE, Izu AE, Douglas JM, et al. Recombinant glycoprotein vaccine for the prevention of genital HSV-2 infection: two randomized controlled trials. Chiron HSV Vaccine Study Group. J Am Med Assoc. 1999;282(4):331-40.

79. Belshe RB, Leone PA, Bernstein DI, Wald A, Levin MJ, Stapleton JT, et al. Efficacy results of a trial of a herpes simplex vaccine. N Engl J Med. 2012;366(1):34-43.

80. Ye L, Zeng R, Bai Y, Roopenian DC, Zhu X. Efficient mucosal vaccination mediated by the neonatal $\mathrm{Fc}$ receptor. Nat Biotechnol. 2011;29(2):158-63.

81. Halford WP, Geltz J, Gershburg E. Pan-HSV-2 IgG antibody in vaccinated mice and guinea pigs correlates with protection against herpes simplex virus 2. PLoS One. 2013;8(6):e65523.

82. Fening SW, Esper F, Scholl D, Huang YT. HSV IgG antibody inhibits virus detection in CSF. J Clin Virol. 2012;55(2):164-7.

83. Chu C-F, Meador MG, Young CG, Strasser JE, Bourne N, Milligan GN. Antibody-mediated protection against genital herpes simplex virus type 2 disease in mice by $\mathrm{Fc}$ gamma receptordependent and -independent mechanisms. J Reprod Immunol. 2008;78(1):58-67.

84. Petro C, Gonzalez PA, Cheshenko N, Jandl T, Khajoueinejad N, Benard A, et al. Herpes simplex type 2 virus deleted in glycoprotein $\mathrm{D}$ protects against vaginal, skin and neural disease. eLife. $2015 ; 4$

85. Zhu J, Peng T, Johnston C, Phasouk K, Kask AS, Klock A, et al. Immune surveillance by $\mathrm{CD} 8 \alpha \alpha+$ skin-resident $\mathrm{T}$ cells in human herpes virus infection. Nature. 2013;497(7450):494-7.S

86. Shin H, Iwasaki A. A vaccine strategy that protects against genital herpes by establishing local memory $\mathrm{T}$ cells. Nature. 2012;491(7424):463-7.

87. Koelle DM, Corey L. Recent progress in herpes simplex virus immunobiology and vaccine research. Clin Microbiol Rev. 2003;16(1):96-113.

88. Roth K, Ferreira VH, Kaushic C. HSV-2 vaccine: current state and insights into development of a vaccine that targets genital mucosal protection. Microbial Pathogenesis. 2012.

89. Rupp R, Bernstein DI. The potential impact of a prophylactic herpes simplex vaccine. Expert Opin Emerg Drugs. 2008;13(1): $41-52$. 
90. Dropulic LK, Cohen JI. The challenge of developing a herpes simplex virus 2 vaccine. Expert Rev Vaccines. 2012;11(12): 1429-40.

91. Zhu XP, Muhammad ZS, Wang JG, Lin W, Guo SK, Zhang W. HSV-2 vaccine: current status and insight into factors for developing an efficient vaccine. Viruses. 2014;6(2):371-90.

92. Awasthi S, Friedman HM. Status of prophylactic and therapeutic genital herpes vaccines. Curr Opin Virol. 2014;6:6-12.

93. Khan AA, Srivastava R, Chentoufi AA, Geertsema R, Thai NT, Dasgupta G, et al. Therapeutic immunization with a mixture of herpes simplex virus type 1 glycoprotein D derived "asymptomatic" human CD8+ T-cell epitopes decreases spontaneous ocular shedding in latently infected HLA transgenic rabbits: association with low frequency of local PD-1+TIM-3+CD8+ exhausted T cells. J Virol. 2015. This publication demonstrates that latent herpes reactivation responsible for herpes keratitis can be treated therapeutically by altering HSV-specific epitope recognition by the host immune system. This work suggests that vaccine approaches can be developed to treat already infected individuals. In the review article, we disclose that the VC2 live-attenuated vaccine has potential for conferring protection against herpes keratitis and may be used as a vector to alter pre-existing immune responses.

94. Srivastava R, Khan AA, Spencer D, Vahed H, Lopes PP, Thai NT, et al. HLA-A02:01-restricted epitopes identified from the herpes simplex virus tegument protein VP11/12 preferentially recall polyfunctional effector memory $\mathrm{CD} 8+\mathrm{T}$ cells from seropositive asymptomatic individuals and protect humanized HLA-A*02:01 transgenic mice against ocular herpes. J Immunol. 2015;194(5): 2232-48.

95. Bernard MC, Barban V, Pradezynski F, de Montfort A, Ryall R, Caillet $\mathrm{C}$, et al. Immunogenicity, protective efficacy, and nonreplicative status of the HSV-2 vaccine candidate HSV529 in mice and guinea pigs. PLoS One. 2015;10(4):e0121518.

96. Geltz JJ, Gershburg E, Halford WP. Herpes simplex virus 2 (HSV-2) infected cell proteins are among the most dominant antigens of a live-attenuated HSV-2 vaccine. PLoS One. 2015;10(2):e0116091.

97. Cuburu N, Wang K, Goodman KN, Pang YY, Thompson CD, Lowy DR, et al. Topical herpes simplex virus 2 (HSV-2) vaccination with human papillomavirus vectors expressing $\mathrm{gB} / \mathrm{gD}$ ectodomains induces genital-tissue-resident memory CD8+ T cells and reduces genital disease and viral shedding after HSV-2 challenge. J Virol. 2015;89(1):83-96.

98. Matundan H, Mott KR, Ghiasi H. Role of CD8+ T cells and lymphoid dendritic cells in protection from ocular herpes simplex virus 1 challenge in immunized mice. J Virol. 2014;88(14): 8016-27.

99. Mott KR, Allen SJ, Zandian M, Akbari O, Hamrah P, Maazi H, et al. Inclusion of CD80 in HSV targets the recombinant virus to PD-L1 on DCs and allows productive infection and robust immune responses. PLoS One. 2014;9(1):e87617.

100. Gorander S, Ekblad M, Bergstrom T, Liljeqvist JA. Antiglycoprotein $\mathrm{g}$ antibodies of herpes simplex virus 2 contribute to complete protection after vaccination in mice and induce antibody-dependent cellular cytotoxicity and complementmediated cytolysis. Viruses. 2014;6(11):4358-72.

101. Awasthi S, Balliet JW, Flynn JA, Lubinski JM, Shaw CE, DiStefano DJ, et al. Protection provided by a herpes simplex virus 2 (HSV-2) glycoprotein C and D subunit antigen vaccine against genital HSV-2 infection in HSV-1-seropositive guinea pigs. $\mathrm{J}$ Virol. 2014;88(4):2000-10.

102. Awasthi S, Huang J, Shaw C, Friedman HM. Blocking herpes simplex virus 2 glycoprotein $\mathrm{E}$ immune evasion as an approach to enhance efficacy of a trivalent subunit antigen vaccine for genital herpes. J Virol. 2014;88(15):8421-32.
103. Zhang P, Xie L, Balliet JW, Casimiro DR, Yao F. A herpes simplex virus 2 (HSV-2) glycoprotein $\mathrm{D}$-expressing nonreplicating dominant-negative HSV-2 virus vaccine is superior to a $\mathrm{gD} 2 \mathrm{sub}$ unit vaccine against HSV-2 genital infection in guinea pigs. PLoS One. 2014;9(6):e101373.

104. Visalli RJ, Natuk RJ, Kowalski J, Guo M, Blakeney S, Gangolli S, et al. Vaccination with a HSV-2 UL24 mutant induces a protective immune response in murine and guinea pig vaginal infection models. Vaccine. 2014;32(12):1398-406.

105.• Stanfield BA, Stahl J, Chouljenko VN, Subramanian R, Charles AS, Saied AA, et al. A single intramuscular vaccination of mice with the HSV-1 VC2 virus with mutations in the glycoprotein K and the membrane protein UL20 confers full protection against lethal intravaginal challenge with virulent HSV-1 and HSV-2 strains. PLoS One. 2014;9(10):e109890. This publication demonstrates that complete protection against different serotypes of HSV can be achieved by vaccination with a live-attenuated vaccine. The study shows that a live-attenuated HSV-1 vaccine can protect against HSV-2 infection due to the presence of type common epitopes that elicit protective immune responses against both viruses.

106. Sicurella M, Nicoli F, Gallerani E, Volpi I, Berto E, Finessi V, et al. An attenuated herpes simplex virus type 1 (HSV1) encoding the HIV-1 Tat protein protects mice from a deadly mucosal HSV1 challenge. PLoS One. 2014;9(7):e100844.

107. Sato A, Suwanto A, Okabe M, Sato S, Nochi T, Imai T, et al. Vaginal memory $\mathrm{T}$ cells induced by intranasal vaccination are critical for protective $T$ cell recruitment and prevention of genital HSV-2 disease. J Virol. 2014;88(23):13699-708.

108. Dervillez X, Qureshi H, Chentoufi AA, Khan AA, Kritzer E, Yu DC, et al. Asymptomatic HLA-A*02:01-restricted epitopes from herpes simplex virus glycoprotein $\mathrm{B}$ preferentially recall polyfunctional CD8+ T cells from seropositive asymptomatic individuals and protect HLA transgenic mice against ocular herpes. $\mathrm{J}$ Immunol. 2013;191(10):5124-38.

109. Santana VC, Diniz MO, Cariri FA, Ventura AM, Cunha-Neto E, Almeida RR, et al. Bicistronic DNA vaccines simultaneously encoding HIV, HSV and HPV antigens promote CD8(+) T cell responses and protective immunity. PLoS One. 2013;8(8):e71322.

110. Ghasemi M, Erturk M, Buruk K, Sonmez M. Induction of potent protection against acute and latent herpes simplex virus infection in mice vaccinated with dendritic cells. Cytotherapy. 2013;15(3): 352-61.

111. Iyer AV, Pahar B, Chouljenko VN, Walker JD, Stanfield B, Kousoulas KG. Single dose of glycoprotein K (gK)-deleted HSV-1 live-attenuated virus protects mice against lethal vaginal challenge with HSV-1 and HSV-2 and induces lasting T cell memory immune responses. Virol J. 2013;10:317.

112. Dutton JL, Li B, Woo WP, Marshak JO, Xu Y, Huang ML, et al. A novel DNA vaccine technology conveying protection against a lethal herpes simplex viral challenge in mice. PLoS One. 2013;8(10):e76407.

113. Cortesi R, Ravani L, Rinaldi F, Marconi P, Drechsler M, Manservigi $\mathrm{M}$, et al. Intranasal immunization in mice with nonionic surfactants vesicles containing HSV immunogens: a preliminary study as possible vaccine against genital herpes. Int J Pharm. 2013;440(2):229-37.

114. Wang K, Kappel JD, Canders C, Davila WF, Sayre D, Chavez M, et al. A herpes simplex virus 2 glycoprotein D mutant generated by bacterial artificial chromosome mutagenesis is severely impaired for infecting neuronal cells and infects only Vero cells expressing exogenous HVEM. J Virol. 2012;86(23):12891-902.

115. Wizel B, Persson J, Thorn K, Nagy E, Harandi AM. Nasal and skin delivery of IC31((R))-adjuvanted recombinant HSV-2 gD protein confers protection against genital herpes. Vaccine. 2012;30(29):4361-8. 
116. Delagrave S, Hernandez H, Zhou C, Hamberger JF, Mundle ST, Catalan J, et al. Immunogenicity and efficacy of intramuscular replication-defective and subunit vaccines against herpes simplex virus type 2 in the mouse genital model. PLoS One. 2012;7(10): e46714.

117. Awasthi S, Zumbrun EE, Si H, Wang F, Shaw CE, Cai M, et al. Live attenuated herpes simplex virus 2 glycoprotein $\mathrm{E}$ deletion mutant as a vaccine candidate defective in neuronal spread. $\mathrm{J}$ Virol. 2012;86(8):4586-98.

118. Zhang X, Dervillez X, Chentoufi AA, Badakhshan T, Bettahi I, Benmohamed L. Targeting the genital tract mucosa with a lipopeptide/recombinant adenovirus prime/boost vaccine induces potent and long-lasting CD8+ T cell immunity against herpes: importance of MyD88. J Immunol. 2012;189(9):4496-509.

119. Schrimpf JE, Tu EM, Wang H, Wong YM, Morrison LA. B7 costimulation molecules encoded by replication-defective, vhsdeficient HSV-1 improve vaccine-induced protection against corneal disease. PLoS One. 2011;6(8):e22772.

120. Hu K, Dou J, Yu F, He X, Yuan X, Wang Y, et al. An ocular mucosal administration of nanoparticles containing DNA vaccine pRSC-gD-IL-21 confers protection against mucosal challenge with herpes simplex virus type 1 in mice. Vaccine. 2011;29(7): 1455-62.

121. $\mathrm{Hu} \mathrm{K}, \mathrm{He} \mathrm{X}, \mathrm{Yu}$ F, Yuan X, Hu W, Liu C, et al. Immunization with DNA vaccine expressing herpes simplex virus type $1 \mathrm{gD}$ and IL21 protects against mouse herpes keratitis. Immunol Investig. 2011;40(3):265-78.

122. Pouriayevali MH, Bamdad T, Parsania M, Sari RD. Full length antigen priming enhances the CTL epitope-based DNA vaccine efficacy. Cell Immunol. 2011;268(1):4-8.

123. Bernstein DI, Earwood JD, Bravo FJ, Cohen GH, Eisenberg RJ, Clark JR, et al. Effects of herpes simplex virus type 2 glycoprotein vaccines and CLDC adjuvant on genital herpes infection in the guinea pig. Vaccine. 2011;29(11):2071-8.

124. Khodai T, Chappell D, Christy C, Cockle P, Eyles J, Hammond D, et al. Single and combination herpes simplex virus type 2 glycoprotein vaccines adjuvanted with $\mathrm{CpG}$ oligodeoxynucleotides or monophosphoryl lipid A exhibit differential immunity that is not correlated to protection in animal models. Clin Vaccine Immunol CVI. 2011;18(10):1702-9.

125. Awasthi S, Lubinski JM, Shaw CE, Barrett SM, Cai M, Wang F, et al. Immunization with a vaccine combining herpes simplex virus 2 (HSV-2) glycoprotein $\mathrm{C}(\mathrm{gC})$ and $\mathrm{gD}$ subunits improves the protection of dorsal root ganglia in mice and reduces the frequency of recurrent vaginal shedding of HSV-2 DNA in guinea pigs compared to immunization with $\mathrm{gD}$ alone. J Virol. 2011;85(20):10472-86.

126. Wang X, Xie G, Liao J, Yin D, Guan W, Pan M, et al. Design and evaluation of a multi-epitope assembly peptide (MEAP) against herpes simplex virus type 2 infection in BALB/c mice. Virol $\mathrm{J}$. 2011;8:232

127. Halford WP, Puschel R, Gershburg E, Wilber A, Gershburg S, Rakowski B. A live-attenuated HSV-2 ICP0 virus elicits 10 to 100 times greater protection against genital herpes than a glycoprotein D subunit vaccine. PLoS One. 2011;6(3):e17748.

128. Tirabassi RS, Ace CI, Levchenko T, Torchilin VP, Selin LK, Nie $\mathrm{S}$, et al. A mucosal vaccination approach for herpes simplex virus type 2. Vaccine. 2011;29(5):1090-8.

129. Morello CS, Levinson MS, Kraynyak KA, Spector DH. Immunization with herpes simplex virus 2 (HSV-2) genes plus inactivated HSV-2 is highly protective against acute and recurrent HSV-2 disease. J Virol. 2011;85(7):3461-72.

130. Hashemi H, Bamdad T, Jamali A, Pouyanfard S, Mohammadi MG. Evaluation of humoral and cellular immune responses against HSV-1 using genetic immunization by filamentous phage particles: a comparative approach to conventional DNA vaccine. $\mathrm{J}$ Virol Methods. 2010;163(2):440-4.

131. Bernstein DI, Farley N, Bravo FJ, Earwood J, McNeal M, Fairman $\mathrm{J}$, et al. The adjuvant CLDC increases protection of a herpes simplex type 2 glycoprotein D vaccine in guinea pigs. Vaccine. 2010;28(21):3748-53.

132. Reszka NJ, Dudek T, Knipe DM. Construction and properties of a herpes simplex virus 2 dl5-29 vaccine candidate strain encoding an HSV-1 virion host shutoff protein. Vaccine. 2010;28(15): 2754-62.

133. Halford WP, Puschel R, Rakowski B. Herpes simplex virus 2 ICP0 mutant viruses are avirulent and immunogenic: implications for a genital herpes vaccine. PLoS One. 2010;5(8):e12251.

134. Kask AS, Chen X, Marshak JO, Dong L, Saracino M, Chen D, et al. DNA vaccine delivery by densely-packed and short microprojection arrays to skin protects against vaginal HSV-2 challenge. Vaccine. 2010;28(47):7483-91.

135. Roth K, Ferreira VH, Kaushic C. HSV-2 vaccine: current state and insights into development of a vaccine that targets genital mucosal protection. Microb Pathog. 2013;58:45-54.

136. Stanberry LR, Spruance SL, Cunningham AL, Bernstein DI, Mindel A, Sacks S, et al. Glycoprotein-D-adjuvant vaccine to prevent genital herpes. N Engl J Med. 2002;347(21):1652-61.

137. Belshe RB, Heineman TC, Bernstein DI, Bellamy AR, Ewell M, van der Most $\mathrm{R}$, et al. Correlate of immune protection against HSV-1 genital disease in vaccinated women. J Infect Dis. 2014;209(6):828-36.

138. Awasthi S, Friedman HM. A paradigm shift: vaccine-induced antibodies as an immune correlate of protection against herpes simplex virus type 1 genital herpes. J Infect Dis. 2014;209(6):813-5.

139. Dasgupta G, Chentoufi AA, Kalantari M, Falatoonzadeh P, Chun $\mathrm{S}$, Lim CH, et al. Immunodominant "asymptomatic" herpes simplex virus 1 and 2 protein antigens identified by probing wholeORFome microarrays with serum antibodies from seropositive asymptomatic versus symptomatic individuals. J Virol. 2012;86(8):4358-69.

140. Mo A, Musselli C, Chen H, Pappas J, Leclair K, Liu A, et al. A heat shock protein based polyvalent vaccine targeting HSV-2: CD4 $(+)$ and $\mathrm{CD} 8(+)$ cellular immunity and protective efficacy. Vaccine. 2011;29(47):8530-41.

141. Wald A, Koelle DM, Fife K, Warren T, Leclair K, Chicz RM, et al. Safety and immunogenicity of long HSV-2 peptides complexed with rhHsc70 in HSV-2 seropositive persons. Vaccine. 2011;29(47):8520-9.

142. Cattamanchi A, Posavad CM, Wald A, Baine Y, Moses J, Higgins TJ, et al. Phase I study of a herpes simplex virus type 2 (HSV-2) DNA vaccine administered to healthy, HSV-2-seronegative adults by a needle-free injection system. Clin Vaccine Immunol. 2008;15(11):1638-43.

143. Meseda CA, Stout RR, Weir JP. Evaluation of a needle-free delivery platform for prime-boost immunization with DNA and modified vaccinia virus Ankara vectors expressing herpes simplex virus 2 glycoprotein D. Viral Immunol. 2006;19(2):250-9.

144. Brittle EE, Wang F, Lubinski JM, Bunte RM, Friedman HM. A replication-competent, neuronal spread-defective, live attenuated herpes simplex virus type 1 vaccine. J Virol. 2008;82(17): 8431-41.

145. Prichard MN, Kaiwar R, Jackman WT, Quenelle DC, Collins DJ, Kern ER, et al. Evaluation of AD472, a live attenuated recombinant herpes simplex virus type 2 vaccine in guinea pigs. Vaccine. 2005;23(46-47):5424-31.

146. van Lint AL, Torres-Lopez E, Knipe DM. Immunization with a replication-defective herpes simplex virus 2 mutant reduces herpes simplex virus 1 infection and prevents ocular disease. Virology. 2007;368(2):227-31. 
147. Dudek T, Mathews LC, Knipe DM. Disruption of the U(L) 41 gene in the herpes simplex virus 2 d15-29 mutant increases its immunogenicity and protective capacity in a murine model of genital herpes. Virology. 2008;372(1):165-75.

148. Hoshino Y, Pesnicak L, Dowdell KC, Lacayo J, Dudek T, Knipe $\mathrm{DM}$, et al. Comparison of immunogenicity and protective efficacy of genital herpes vaccine candidates herpes simplex virus 2 d15-29 and d15-29-41L in mice and guinea pigs. Vaccine. 2008;26(32): $4034-40$.

149. Da Costa XJ, Morrison LA, Knipe DM. Comparison of different forms of herpes simplex replication-defective mutant viruses as vaccines in a mouse model of HSV-2 genital infection. Virology. 2001;288(2):256-63.

150. Akhrameyeva NV, Zhang P, Sugiyama N, Behar SM, Yao F. Development of a glycoprotein D-expressing dominant-negative and replication-defective herpes simplex virus 2 (HSV-2) recombinant viral vaccine against HSV-2 infection in mice. J Virol. 2011;85(10):5036-47.

151. Brans R, Akhrameyeva NV, Yao F. Prevention of genital herpes simplex virus type 1 and 2 disease in mice immunized with a $\mathrm{gD}$ expressing dominant-negative recombinant HSV-1. J Invest Dermatol. 2009;129(10):2470-9.

152. Brans R, Yao F. Immunization with a dominant-negative recombinant herpes simplex virus (HSV) type 1 protects against HSV-2 genital disease in guinea pigs. BMC Microbiol. 2010;10:163.

153. Augustinova H, Hoeller D, Yao F. The dominant-negative herpes simplex virus type 1 (HSV-1) recombinant CJ83193 can serve as an effective vaccine against wild-type HSV-1 infection in mice. $\mathrm{J}$ Virol. 2004; 78(11):5756-65.

154. Gyotoku T, Ono F, Aurelian L. Development of HSV-specific CD4+ Th1 responses and CD8+ cytotoxic T lymphocytes with antiviral activity by vaccination with the HSV-2 mutant ICP10DeltaPK. Vaccine. 2002;20(21-22):2796-807.

155. Casanova G, Cancela R, Alonzo L, Benuto R, Magana MC, Hurley DR, et al. A double-blind study of the efficacy and safety of the ICP10deltaPK vaccine against recurrent genital HSV-2 infections. Cutis. 2002;70(4):235-9.

156. de Bruyn G, Vargas-Cortez M, Warren T, Tyring SK, Fife KH, Lalezari J, et al. A randomized controlled trial of a replication defective ( $\mathrm{gH}$ deletion) herpes simplex virus vaccine for the treatment of recurrent genital herpes among immunocompetent subjects. Vaccine. 2006;24(7):914-20.

157. Murphy CG, Lucas WT, Means RE, Czajak S, Hale CL, Lifson $\mathrm{JD}$, et al. Vaccine protection against simian immunodeficiency virus by recombinant strains of herpes simplex virus. J Virol. 2000;74(17):7745-54.

158. Watanabe D, Brockman MA, Ndung'u T, Mathews L, Lucas WT, Murphy CG, et al. Properties of a herpes simplex virus multiple immediate-early gene-deleted recombinant as a vaccine vector. Virology. 2007;357(2):186-98.

159. Harrington KJ, Hingorani M, Tanay MA, Hickey J, Bhide SA, Clarke PM, et al. Phase I/II study of oncolytic HSV GM-CSF in combination with radiotherapy and cisplatin in untreated stage III/ IV squamous cell cancer of the head and neck. Clin Cancer Res. 2010;16(15):4005-15.

160. Andtbacka RH, Kaufman HL, Collichio F, Amatruda T, Senzer N, Chesney J, et al. Talimogene laherparepvec improves durable response rate in patients with advanced melanoma. J Clin Oncol. 2015. This publication identifies the first highly promising therapeutic application of a live-attenuated herpes vector that has successfully completed phase III testing and expected to be licensed for human use. This will pave the way for the use of other live-attenuated herpesviruses for vaccine and cancer treatment.

161. Marin M, Güris D, Chaves SS, Schmid S, Seward JF, Advisory Committee on Immunization Practices CfDC, et al. Prevention of varicella: recommendations of the Advisory Committee on Immunization Practices (ACIP). MMWR Recomm Rep. 2007;56(RR-4):1-40.

162. Marin M, Meissner HC, Seward JF. Varicella prevention in the United States: a review of successes and challenges. Pediatrics. 2008;122(3):e744-51.

163. Schmid DS, Jumaan AO. Impact of varicella vaccine on varicellazoster virus dynamics. Clin Microbiol Rev. 2010;23(1):202-17.

164. Seward JF, Marin M, Vázquez M. Varicella vaccine effectiveness in the US vaccination program: a review. J Infect Dis. 2008;197 Suppl 2:S82-9.

165. David AT, Baghian A, Foster TP, Chouljenko VN, Kousoulas KG. The herpes simplex virus type 1 (HSV-1) glycoprotein $\mathrm{K}(\mathrm{gK})$ is essential for viral corneal spread and neuroinvasiveness. Curr Eye Res. 2008;33(5):455-67.

166. David AT, Saied A, Charles A, Subramanian R, Chouljenko VN, Kousoulas KG. A herpes simplex virus 1 (McKrae) mutant lacking the glycoprotein $\mathrm{K}$ gene is unable to infect via neuronal axons and egress from neuronal cell bodies. mBio. 2012;3(4): e00144-12.

167. Saied AA, Chouljenko VN, Subramanian R, Kousoulas KG. A replication competent HSV-1(McKrae) with a mutation in the amino-terminus of glycoprotein $\mathrm{K}(\mathrm{gK})$ is unable to infect mouse trigeminal ganglia after cornea infection. Current Eye Research. 2014.

168. Cairns TM, Huang ZY, Whitbeck JC, Ponce de Leon M, Lou H, Wald A, et al. Dissection of the antibody response against herpes simplex virus glycoproteins in naturally infected humans. J Virol. 2014;88(21):12612-22.

169. Posavad CM, Remington M, Mueller DE, Zhao L, Magaret AS, Wald A, et al. Detailed characterization of $\mathrm{T}$ cell responses to herpes simplex virus-2 in immune seronegative persons. J Immunol. 2010;184(6):3250-9.

170. St Leger AJ, Jeon S, Hendricks RL. Broadening the repertoire of functional herpes simplex virus type 1 -specific CD8+ T cells reduces viral reactivation from latency in sensory ganglia. $\mathrm{J}$ Immunol. 2013;191(5):2258-65. 